\title{
A BUSINESS MODEL IN AGRICULTURAL PRODUCTION IN SERBIA, DEVELOPING TOWARDS SUSTAINABILITY
}

Mila Zecevic ${ }^{1}$, Lato Pezo ${ }^{2}$, Marija Bodroza-Solarov ${ }^{3}$, Tea Brlek ${ }^{4}$, Jelena Krulj ${ }^{5}$, Jovana Kojićn, Boško Marić ${ }^{7}$

*Corresponding author E-mail: latopezo@yahoo.co.uk

A R T I C L E I N F O
Original Article
Received: 03 February 2018
Accepted: 11 June 2018
doi:10.5937/ekoPolj1902437Z
UDC 005.22:[338.432:502.131.1(497.11)

Keywords:

business model, agricultural production, Cobb-Douglas, Artificial Neural Network, Serbia

JEL:C15

\begin{abstract}
A B S T R A C T
Agricultural production is a Serbian main economic sector, presenting a base for the food industry. By analysing the public available data of the agriculture sector, applying a newly developed business model it is possible to assess the current situation and to realize the relation between variables, which can also be used for prediction of future trends in agricultural production and food industry. Within this paper an attempt was made to develop a novel artificial neural network model for better understanding the relation between the observed parameters and to estimate the efficiency in sustainability achievement and sector potential The well-known CobbDouglas production model was compared to the newly developed model. The presented models could be used to achieve the transformation towards a circular bioeconomy, by developing the national strategies for sustainable agricultural production, with the aim of better utilization of resources and reduction of wastes.
\end{abstract}

(C) 2019 EA. All rights reserved.

1 Mila Zecevic, PhD student, Faculty of Economics, University of Ljubljana, Kardeljeva Ploščad 17, 1000 Ljubljana, Slovenia, zecevic.mila@yahoo.com

2 Lato Pezo, PhD, Institute of General and Physical Chemistry, University of Belgrade, Studentski Trg 12 - 16, 11000 Beograd, Serbia, +381 113283 185, latopezo@yahoo.co.uk, https://orcid.org/0000-0002-0704-3084

3 Marija Bodroza-Solarov, PhD, Institute of Food Technology Novi Sad, University of Novi Sad, Bulevar Cara Lazara 1, 21000 Novi Sad, Serbia,+381 21485 3771,marija.bodroza@, fins.uns.ac.rs, https://orcid.org/0000-0001-8151-6276

4 Tea Brlek, PhD, Institute of Food Technology Novi Sad, University of Novi Sad, Bulevar Cara Lazara 1, 21000 Novi Sad, Serbia, +381 21485 3751, tea.brlek@fins.uns.ac.rs

5 Jelena Krulj, PhD, Institute of Food Technology Novi Sad, University of Novi Sad, Bulevar Cara Lazara 1, 21000 Novi Sad, Serbia, +381 21485 3798, jelena.krulj@fins.uns.ac.rs, https://orcid.org/0000-0001-7348-3961

6 Jovana Kojić, academic position, Institute of Food Technology Novi Sad, University of Novi Sad, Bulevar Cara Lazara 1, 21000 Novi Sad, Serbia, +381 21485 3798, jovana. kojic@fins.uns.ac.rs, https://orcid.org/0000-0002-8816-9892

7 Boško Marić, PhD student, Institute of Food Technology Novi Sad, University of Novi Sad, Bulevar Cara Lazara 1, 21000 Novi Sad, Serbia,+381 21485 3797, bosko.maric@fins.uns. ac.rs, https://orcid.org/0000-0003-4264-8086 


\section{Introduction}

Since 2012 the EU is oriented towards higher sustainability of agricultural production to improve cost-effectiveness, process efficiency and green credentials. In doing so, in 2012 the EU Commission adopted a strategy named "Innovating for sustainable growth: A bioeconomy for Europe", with the main aim to "radically change its approach in production, consumption, processing, storage, recycling and disposal of biological resources" (The Bioeconomy Strategy, 2012). In the strategy revision in 2017, its efficiency was assessed as positive, while the emphasis on its increasing relevance in modern European society (European Commission, 2017). The main sector of Serbian economy is agricultural and food industry. Serbia should, like other EU countries aspire to achieve a sustainable production in all aspects, especially in agriculture, and to enter a transition into bioeconomy, as much as possible. The key to achieve transformation towards a circular bioeconomy is to develop national strategies for sustainable agricultural production, with the aim of better utilization of resources and reduction of wastes. Increasing sustainability, as a main point in the bioeconomy, can lead to positive environmental and social impact followed by economic growth (Pfau et al, 2014, Ramcilovic-Suominen and Pülzl, 2016). Bioeconomy is set to use renewable resources in all areas (Johnson and Altman, 2014) which are highly available from agricultural production. Agricultural production presents the base for the food industry as well for bioenergy (biomass), which present Serbia's window of opportunity in developing bioeconomy. Therefore possible market opportunity for agriculture can be through value added products in traditional sectors, such as food production and the establishment of non-food markets in the field of bioenergy, which can boost rural areas (EuropaBio, 2011; Zabaniotou et al., 2017). To achieve the set goals it is essential to evaluate the country's potential in the main sectors of economy by analysing inputs and outputs of production. To ensure food security and resource efficiency the EU has set a goal to establish a bioeconomy until 2050 (Kalt et al, 2016). Therefore EU countries have analysed their own potentials and opportunities in establishing bioeconomy such as Germany (Efken et al, 2016), Austria (Kalt et al, 2016), The Netherlands (Heijman, 2016), and some have launched bioeconomy initiatives including France, Germany, The Netherlands, Sweden and Finland (Loiseau et al, 2016).

The European Bioeconomy Panel has defined that the establishment of the bioeconomy, requires precise data on the biomass availability as an essential base which can help estimate the dependence of bio-based products (Henning et al, 2016). It is of great importance to define where the county stands in the transition to a circular economy, and the starting point is sustainable agricultural production. Therefore, we have analysed this sector to see where Serbian opportunities are, which division has the perspective, and which needs to be boosted.

A mathematical approach has been used to evaluate the agricultural sector. A similar 
approach assessing the efficiency of the bioeconomy in Latvia has been used by Muizniece et al, 2016. A comprehensive study of various mathematical techniques in treatment of the traditional agricultural production economics topics is presented by Debertin, 2012. The used mathematical tools focus on the neoclassical mathematical models, and the specific importance is devoted to Cobb-Douglas production function.

The estimate of the agricultural production using the three basic factors of production in Canada is presented by Echevarria, 1998. Within this study, the Cobb-Douglass function is characterised as a useful tool for macroeconomic, growth, and development studies. In the study performed by Yuan, 2011, the analysis of variation in agricultural inputs and outputs and their relations in Hebei Province of China was investigated using CobbDouglas production function. The elasticity indexes in the Cobb-Douglas function is in detail described in the article written by Pandey et al., 1982, in which the annual time series data for the period 1950-76 are used to estimate the price elasticity of aggregate Australian agricultural supply. In the paper written by Vanzetti and Quiggin, 1985, the investment analysis is identified at the microeconomic level, by considering the basis of individual decisions, and tested empirically at the aggregate level.

In a study written by Randall, 2008, the Cobb-Douglas function is used to indicate the sustainability of the agricultural production in Australia. The influence of environmental factors regarding agro-economical production is studied by Thampapillai, 2011. Recently, Cobb-Douglas production function was also used for assessing productivity and efficiency of agriculture in developing countries, including India (Mishra \& Das, 2017; Ghoshal \& Goswami, 2017) and Nigeria (Biam, Okorie \& Nwibo, 2016).

Artificial neural network mathematical models are a computational approach used in nowadays computer science in many research disciplines, including economics. This model is based on a collection of neural units (so called artificial neurons), which are connected with each other, enabling their effect by the activation of connected neural units. In a study performed by Ribeiro and Oliveira, 2011, artificial neural network (ANN) model was used for prediction of prices in an economical model in the sugaralcohol sector. The effects of the social welfare of the apple import in New Zealand are discussed in a paper by Cook, et al., 2011. In this study a demonstration of an economic framework, which takes into account both the gains from trade and the costs of invasive species outbreaks, can inform decision-makers when making decisions.

The environmental effect, as very important one in agricultural production, and the influence of such parameters can be described using the ANN model. For instance, the influence of El Nino on the market dynamics of major vegetable oil prices is discussed in a study performed by Ubilava and Holt, 2013, using the ANN model. Some of the recent researches using ANN model include assessments of biodiesel production (Maran \& Priya, 2015), sunflower seed yields (Zeng et al., 2017) and waste cooking oil (Soji-Adekunle et al., 2018). 
The focus points in this paper were agricultural inputs and outputs from the year 2007 to 2013. The goal of this paper is to provide an assessment and comparison between two models, agricultural input-output potential model based on Cobb-Douglas production function and Artificial Neural Network model. Furthermore, the main influence factors affecting the agricultural output in Serbia are investigated in both models. This has created a business model for agricultural production as a tool in achieving sustainability more efficiently and more quickly, allowing us to perceive the current condition as well as to foresee the economic trends in the near future. The method has been developed to assess the potential of the initial economical sector (agriculture) in Serbia. The main aim of the paper was to provide better understanding of the two models used to estimate the efficiency in sustainability achievement and sector potential, as well as their comparison.

\section{Materials and methods}

\section{Data collection}

The economic statistics data for Serbia from 2007 to 2013, including:agricultural productivity, agricultural value added, crop production index, employment in agriculture, fertilizer use and food production index were obtained from the Global Economy site (www.theglobaleconomy.com) and FAO (www.fao.org). The output data used in the models were: GDP share agriculture (GDPA), overall agricultural output (AOUT), agricultural goods output (AGOUT), crop production (CROP), the production of cereals (including seeds) $(C E R)$, the production of industrial crops (ICRO), the production of forage plants $(F O R)$, the production of vegetables and horticultural products (VEG), the production of potato (including seeds) (POT), the production of fruits (FRU) and wine (WINE), other crop products (OCRO), the overall animal production (ANIP), the production of animals (ANIM), the production of cattle (CATT), the production of pigs $(P I G)$ and equines $(E Q U)$, the production of sheep and goats (SHEEP), the production of poultry, (POUL) the overall collection of animal products (ANIMP2), milk products (MILK), eggs production (EGG), other animal products (OANI) and agricultural services (ASERV). The output data were obtained from Serbian economic statistical yearbooks (2007 to 2013). The summary of the collected data is presented in Supplement material, Tables S1 and S2.

\section{Agricultural input-output potential model}

In economic theory, the Cobb-Douglas production function is widely used to represent the relationship between the amounts of multiple inputs, as well as the amount of the output that can be created using these inputs. The original Cobb-Douglas production function was developed and statistically tested between 1927 and 1947. Its formulation was the following: 


$$
Y=A \cdot L^{\beta} \cdot K^{\alpha},
$$

where $K$ represents capital, $L$ symbolizes labour, and $A$ represents the contribution of any input other than capital and labour to the total output. The term $A$ can also represent the contribution technological efficiency can have to the total output (Cobb \& Douglas, 1928).

In time, numerous modifications of this formula emerged. Namely, its relative simplicity of calculation makes it very useful and convenient from the mathematical point of view. However, this method received many critics because of its inability to incorporate any deeper knowledge of technology, engineering or management (Houthakker, 1955).

These disadvantages became more emphasized with years, as the importance of knowledge in these areas for economic calculations only grew in the past decades. This also explains the number of modifications this formula has in contemporary economics. In this research, in order to include all the relevant factors in the agricultural field in economics, Cobb-Douglas production function was slightly adjusted as well.

Within here developed model, agricultural input factors include: agricultural productivity $(A P R O)$, agricultural value added $(A V A L)$, employment in agriculture $(E M P)$, fertilizer use $(F E R)$ and food production index $(F P I)$. The relation of agricultural output and input can be expressed as, Yuan, 2011; Apostolov, 2016; Kalt et al., 2016; Muizniece, et al., 2016:

$$
Y=f(A P R O, A V A L, E M P, F E R, F P I)
$$

In economics, the Cobb-Douglas production function is widely used to represent the relationship of an output to inputs and it can be represented as:

$$
Y=A \cdot A P R O^{\alpha} \cdot A V A L^{\beta} \cdot E M P^{\gamma} \cdot F E R^{\delta} \cdot F P I^{\lambda}
$$

Eqn. (2) can be changed to the following form:

$$
\ln Y=A+\alpha \cdot \ln A P R O+\beta \cdot \ln A V A L+\gamma \cdot \ln E M P+\delta \cdot \ln F E R+\lambda \cdot \ln F P I
$$

Where $\alpha, \beta, \gamma, \delta$ and $\lambda$, are the output elasticities of agricultural productivity, agricultural value added, employment in agriculture, fertilizer use and food production index, respectively, while $Y$ is the output of the developed model. If the sum $\alpha+\beta+\gamma+\delta+$ $\lambda<0$, the output is decreasing, and if $\alpha+\beta+\gamma+\delta+\lambda>0$, then the observed output is increasing over the years.

\section{ANN modelling}

A multi-layer perceptron model (MLP), which consisted of three layers (input, hidden and output) was used for modelling. This model has been proven as a quite capable of 
approximating nonlinear functions (Hu \&Weng, 2009; Karlović et al., 2013). Before the calculation, both input and output data were normalized in order to improve the behaviour of the ANN. During this iterative process, input data are repeatedly presented to the network (Grieu et al., 2011; Pezo et al., 2013). Broyden-Fletcher-GoldfarbShanno (BFGS) algorithm was used, as an iterative method for solving unconstrained nonlinear optimization problems in ANN modelling.

Coefficients associated with the hidden layer (weights and biases) are grouped in matrices $W_{1}$ and $B_{1}$. Similarly, coefficients associated with the output layer are grouped in matrices $W_{2}$ and $B_{2}$. It is possible to represent the neural network, by using matrix notation ( $Y$ is the matrix of the output variables, $f_{1}$ and $f_{2}$ are transfer functions in the hidden and output layers, respectively, and $X$ is the matrix of input variables) (Kollo\& von Rosen, 2005):

$$
Y=f_{1}\left(W_{2} \cdot f_{2}\left(W_{1} \cdot X+B_{1}\right)+B_{2}\right)
$$

Weights (elements of matrices $W_{1}$ and $W_{2}$ ) are determined during the ANN learning cycle, which updates them using optimization procedures to minimize the error between network and experimental outputs (Trelea et al., 1997; Pezo et al., 2013), according to the sum of squares (SOS) and BFGS algorithm, used to speed up and stabilize convergence (Basheer\&Hajmeer 2000). The coefficients of determination were used as parameters to check the performance of the obtained ANN model.

\section{Sensitivity analysis}

Sensitivity analysis is a widely accepted technique used in the decision theory for exploring the effects of the uncertainties in the observed parameters of a developed model (Montaño\& Palmer, 2003). Neural networks can perform an approximation to experimental results, which could be partially noisy and partially imprecise data, so sensitivity analysis is necessary to check if the neural network could behave erroneously (Taylor, 2006). On the basis of the developed ANN model, sensitivity analysis was performed in this work, in order to more precisely check the influence of input variables on the observed outputs. The infinitesimal amount $(+0.0001 \%)$ has been added to each input variable, in 10 equally spaced individual points encompassed by the minimum and maximum of the training data.

\section{Results}

The input and output data are presented in Supplement material, Tables S1 and S2. 


\section{Cobb-Douglas production function}

When observing output elasticities, it is also important to make a difference between the coefficients that are elastic $(>1)$ and the ones with inelastic $(<1)$ characteristics. In general, elasticity shows the relationship between the change in output and the change in input used. Elastic relationships show bigger impact of input change on the output change compared to the ones that are inelastic (Baye, 2009).

The regression coefficients we obtained as the results of a calculation (Table 1) show the dominance of inelastic coefficients. Inelastic regression coefficients suggest that the change in output that is triggered by the change in observed input is small.

By examining the data from Table 1, we can also conclude that certain regression coefficients are elastic for most of the output categories. Agricultural productivity output elasticity $(\alpha)$ and food production index $(\lambda)$ have an elastic relationship with output change for most of the output categories listed in Table 1. Such results imply that the change in inputs directly related with these regression coefficients (inputs: agricultural productivity and food production index) can have larger effect on output changes than the changes in inputs whose regression coefficients (elasticities) show lower values (i.e. regression coefficients that are inelastic).

It is however important to emphasize that the inelastic relationships do not represent the lack of the relationship or influence of inputs directly related to inelastic coefficients. While the individual effect of the change in inputs on change in the total output can be considered small, the influence these coefficients have on output change when combined is not to be neglected, which is shown in the calculation as well.

ANOVA was conducted for obtained models, and output variables were tested against the impact of input variables (Supplement material, Table S3). ANOVA analysis revealed that FER is the most important variable for GDPA calculation, while APRO is the most important for the prediction of: AOUT, AGOUT, CROP, CER, ICRO and FOR, while $A V A L$ is the most important for VEG calculation. The influences of $A P R O, A V A L, E M P$ and FER are very influential for POT evaluation, while the impact of APRO, FER and FPI are important for FRU, WINE and OCRO calculation. ANIP, ANIM and PIG are influenced by $A P R O$, according to the developed model. The most important variables for calculation of EQU and POUL are APRO, EMP, FER and FPI. The output variable SHEEP is mostly affected by $A P R O, E M P$ and FER. The input variables APRO, FER and FPI are the most important for the prediction of ANIP2, MILK and EGG. The prediction of $O A N I$ is mostly affected by APRO, while the calculation of ASERV is influenced by $A P R O$ and EMP.

The coefficient of determination $\left(\mathrm{r}^{2}\right)$ for Cobb-Douglas production functions were rather good (0.654-1.000) (Supplement material, Table S3), indicating that some other model (ANN model, for instance) would improve the validity of the model. 


\section{Discussions}

The regression coefficients for the Cobb-Douglas production functions are shown in Table 1. Within this table, the sum of the specific regression coefficients is shown, and the sign of these sums indicates the trend of that specific output. The negative sums of regression coefficients are obtained for: GDPA, ICER, FOR, VEG, POT and SHEEP, while the positive trends are noticed for the following outputs: AOUT, AGOUT, CROP, CER, FRU, WINE, OCRO, ANIP, ANIM, CATT, PIG, EQU, POUL, ANIP2, MILK, EGG, OANI and ASERV.

The growth in the production of fruits and grape (vine) (Table 1), in the observed time period, is the result of the current agricultural development strategy issued by the Serbian Ministry of Agriculture (Official Gazette, 2014). This strategy is based on the analysis of the world market needs, agro-ecological predetermination of Serbia for growing fruits and vines, as well as bilateral agreements on the privileged status in trade relations (for instance with Russia). This production generates also a significant amount of waste (by product) which can be reused in the sense of circular bioeconomy. The scientific studies in Serbia also show an interest in this particular group of agricultural products valorising their waste in added value products. These wastes have been suggested to be implemented in food products to improve the nutritional value and enhance storage stability, due to the content of antioxidant compounds (TumbasSaponjac et al, 2014, Cetojevic-Simin et al, 2015, Tumbas-Saponjac et al, 2016).

Unfortunately vegetable production, in the contrast to the fruit is showing a decrease (Table 1). This is caused by a shorter shelf life of this product compared to fruits, thus making it impossible to be as attractive as fruit in the world market. Storage and perseverance of vegetables (which would prolong its shelf life) are also challenging. The technological systems are often not available or appropriate to handle the amounts of the products supplied. This is especially true when we talk about small producers, which rarely have adequate equipment to store perishable goods and potentially transport them to distant areas. Therefore, the producers are faced with a limitation in the domestic market mainly. However, the domestic market is small, and its purchasing power is low. Therefore, waste is not uncommon when we talk about vegetable and its production in Serbia. Scientific efforts have been made to valorise such waste in a similar manner as fruit wastes (Belovic et al, 2015, Stajcic et al, 2015).

As can be seen from the table 1 industrial crop production has a negative trend in the analysed time period, while the areas under main industrial crops (sugar beet and sunflower) are decreasing. Production of industrial plants such as sugar beet is becoming more risky and less profitable due to decreasing of sugar price in the market, which is caused by increased imports of sugar cane from non EU countries. Sunflower as the second most represented industrial plants in the Serbian agricultural production, was until recently the most profitable production in Serbia. Due to harmonization of 
Serbian laws to EU legislation in the process of integration in EU, Serbia was forced to open the market, thus jeopardizing the edible oil industry in the country. Now, the edible oil industry is not prepared to pay the same price as before, thus placing a farmer in a less attractive position.

Cereals (namely wheat and corn) have a positive trend, which is evident from the table 1. They fill in the gap in agricultural production caused by decrees of industrial crop production. In Southern Europe, small farms are still dominant. This is also true for Serbia, with minor differences (Official Gazette, 2014). Namely, according to the data collected in the Census of Agriculture 2012, in the Republic of Serbia there are 631,522 farms, which use 3,437 million hectares of agricultural land. From the total number of listed farms, only $3.1 \%$ reaches over 20 ha in size, covering $44 \%$ of the total country's utilized agricultural area (hereinafter UAA). On the other side, 5 or less hectar farms are the most present ones, accounting for $77.7 \%$ of the total number of listed farms, and covering $25.2 \%$ of the UAA. The aforementioned differences between Serbia and other Southern Europe countries is in the share of farms that are 2-10 hectars large. These shares are higher in Serbia, where $43 \%$ of farms and $35.3 \%$ of UAA belongs to this category (Official Gazette, 2014). Impoverished small agricultural producers who own under 10 ha of land, which are present with more than $40 \%$ in the overall agricultural production in Serbia (Official Gazette, 2014), are turning to production of more "stable" crops with less risks and lower investments. The residual analysis showed that the mean of residuals were equal to zero, and the standard deviation was between $2.3 \cdot 10^{-3}$ and $1.5 \cdot 10^{-1}$. These results showed a good approximation to a normal distribution around zero with a probability of $95 \%(2 \times \mathrm{SD})$, which means a good generalization ability of the developed model for the range of observed experimental data.

The quality of the model fit was tested in Table 2, and coefficients of determination $\left(\mathrm{r}^{2}\right)$ value should be higher for better fitting of the model to the collected data (Arsenović et al., 2013). 
Table 1. Regression coefficients for the Cobb-Douglas production functions

\begin{tabular}{|c|c|c|c|c|c|c|c|c|}
\hline & GDPA & AOUT & AGOUT & CROP & CER & ICER & FOR & VEG \\
\hline Mean/Interc. & 5.502 & 1.493 & 1.470 & 3.059 & 3.063 & -0.460 & 6.345 & 11.302 \\
\hline$\alpha$ & -0.138 & 1.918 & 1.946 & 1.959 & 2.203 & 3.028 & 1.433 & 1.176 \\
\hline$\beta$ & 0.221 & -0.003 & 0.005 & -0.078 & 0.366 & -0.411 & -0.482 & -2.047 \\
\hline$\gamma$ & -0.428 & 0.688 & 0.686 & 0.393 & 0.401 & 0.461 & 0.305 & 0.136 \\
\hline$\delta$ & -0.301 & 0.230 & 0.228 & -0.046 & -0.165 & 0.149 & -0.135 & -1.372 \\
\hline$\lambda$ & 0.120 & -1.759 & -1.811 & -1.748 & -2.379 & -3.563 & -1.857 & -0.456 \\
\hline \multirow[t]{2}{*}{ SUM } & -0.526 & 1.074 & 1.054 & 0.479 & 0.425 & -0.338 & -0.736 & -2.562 \\
\hline & POT & $F R U$ & WINE & OCRO & $A N I P$ & ANIM & CATT & $P I G$ \\
\hline Mean/Interc. & -1.112 & -2.401 & -11.016 & -1.111 & -4.131 & -6.365 & -3.439 & -11.388 \\
\hline$\alpha$ & 2.837 & 2.099 & -0.615 & -0.972 & 1.902 & 1.922 & 1.443 & 2.167 \\
\hline$\beta$ & -1.038 & 0.412 & 0.694 & 0.086 & 0.219 & -0.004 & 0.155 & -0.189 \\
\hline$\gamma$ & -1.982 & 0.541 & 1.393 & 0.951 & 1.335 & 1.544 & 1.010 & 2.453 \\
\hline$\delta$ & -0.946 & 0.752 & 1.143 & 0.850 & 0.853 & 0.793 & 0.744 & 0.938 \\
\hline$\lambda$ & -0.336 & -2.328 & 3.356 & 1.806 & -1.928 & -1.576 & -1.230 & -1.801 \\
\hline \multirow[t]{2}{*}{ SUM } & -1.466 & 1.475 & 5.969 & 2.720 & 2.381 & 2.680 & 2.122 & 3.570 \\
\hline & $E Q U$ & SHEEP & POUL & ANIP2 & MILK & $E G G$ & OANI & ASERV \\
\hline Mean/Interc. & -26.266 & 7.168 & -10.985 & -1.007 & 0.284 & -4.798 & -19.699 & -2.505 \\
\hline$\alpha$ & 2.814 & 0.845 & 2.736 & 1.887 & 1.661 & 2.146 & 4.474 & 0.837 \\
\hline$\beta$ & 0.604 & -0.182 & 0.416 & 0.737 & 0.815 & 0.657 & -0.768 & -0.326 \\
\hline$\gamma$ & 5.785 & -0.652 & 0.566 & 0.853 & 0.735 & 1.416 & -1.213 & 0.816 \\
\hline$\delta$ & 4.707 & -0.354 & 1.002 & 0.985 & 0.861 & 1.350 & 0.762 & 0.296 \\
\hline$\lambda$ & -7.543 & -0.312 & -2.218 & -2.795 & -2.537 & -3.504 & -2.216 & 0.238 \\
\hline SUM & 6.367 & -0.654 & 2.503 & 1.667 & 1.535 & 2.066 & 1.038 & 1.861 \\
\hline
\end{tabular}

$* \alpha, \beta, \gamma, \delta$ and $\lambda$ - the output elasticities of agricultural productivity, agricultural value added, employment in agriculture, fertilizer use and food production index, respectively. GDPA - GDP share agriculture, $A O U T$ - overall agricultural output, $A G O U T$ - agricultural goods output, $C R O P$ - crop production, CER - the production of cereals (including seeds), ICRO - the production of industrial crops, FOR - the production of forage plants, VEG - the production of vegetables and horticultural products, $P O T$ - the production of potato (including seeds), FRU - the production of fruits, WINE - the production of wine, OCRO - other crop products, ANIP - the overall animal production, ANIM - the production of animals, CATT - the production of cattle, PIG - the production of pigs, EQU - the production of equines, SHEEP - the production of sheep and goats, POUL - the production of poultry, ANIMP2 - the overall collection of animal products, MILK - milk products, EGG - eggs production, OANI - other animal products and ASERV agricultural services. 


\section{Artificial neural network}

The acquired optimal neural network model, showed a good generalization capability to experimental data, and can be used to predict the accurate output for a broad range of the input parameters. According to ANN performance, it was noticed that the optimal number of neurons in the hidden layer is 6 , when using it for the prediction of output variables: GDPA, AOUT, AGOUT, CROP, CER, ICRO, FOR, VEG, POT, FRU, WINE, OCRO, ANIP, ANIM, CATT, PIG, EQU, SHEEP, POUL, ANIMP2, MILK, EGG, OANI and ASERV (network MLP 5-6-24).

The goodness of fit, between the data obtained from the Serbian economic statistical yearbooks and ANN model calculated outputs, represented as ANN performance (sum of $r^{2}$ ), are shown in Table 2.High values of $r^{2}$ for both models were obtained (overall 1.000 for ANN model, compared to $0.654-1.00$ for Cobb-Douglas production functions).

The ANN model had an insignificant lack of fit tests, which means that all the models represented the data satisfactorily. A high $\mathrm{r}^{2}$ is indicative that the variation was accounted and that the data fitted satisfactorily to the proposed model (Montgomery, 1984; Madamba, 2002).

Table 2. The comparison of coefficients of determination obtained for Cobb-Douglass production $(\mathrm{CB})$ function and the ANN model

\begin{tabular}{|l|c|c|l|r|r|l|r|l|}
\hline Output & \multicolumn{1}{c|}{ CB } & ANN & Output & \multicolumn{1}{c|}{ CB } & ANN & Output & CB & ANN \\
\hline GDPA & 0.993 & 1.000 & POT & 0.983 & 1.000 & EQU & 0.946 & 1.000 \\
\hline AOUT & 0.946 & 1.000 & FRU & 0.992 & 1.000 & SHEEP & 0.764 & 1.000 \\
\hline AGOUT & 0.945 & 1.000 & WINE & 0.983 & 1.000 & POUL & 0.926 & 1.000 \\
\hline CROP & 0.945 & 1.000 & OCRO & 0.654 & 1.000 & ANIP2 & 1.000 & 1.000 \\
\hline CER & 0.953 & 1.000 & ANIP & 0.958 & 1.000 & MILK & 1.000 & 1.000 \\
\hline ICER & 0.972 & 1.000 & ANIM & 0.921 & 1.000 & EGG & 0.999 & 1.000 \\
\hline FOR & 0.858 & 1.000 & CATT & 0.924 & 1.000 & OANI & 0.953 & 1.000 \\
\hline VEG & 0.958 & 1.000 & PIG & 0.941 & 1.000 & ASERV & 0.997 & 1.000 \\
\hline
\end{tabular}

GDPA - GDP share agriculture, AOUT - overall agricultural output, AGOUT - agricultural goods output, $C R O P$ - crop production, $C E R$ - the production of cereals (including seeds), $I C R O$ - the production of industrial crops, FOR - the production of forage plants, VEG - the production of vegetables and horticultural products, $P O T$ - the production of potato (including seeds), FRU - the production of fruits, WINE - the production of wine, OCRO - other crop products, ANIP - the overall animal production, ANIM - the production of animals, CATT - the production of cattle, PIG - the production of pigs, EQU - the production of equines, SHEEP - the production of sheep and goats, POUL - the production of poultry, ANIMP2 - the overall collection of animal products, MILK - milk products, EGG - eggs production, OANI - other animal products and ASERV - agricultural services.

ANN models were used to predict output variables very well, i. e., the predicted output values were close to the desired values, in terms of $r^{2}$ value (Pezo et al., 2013; Chattopadhyay\&Rangarajan, 2014). 


\section{Sensitivity analysis}

The influence of the input variables at a specific position in the input space, over the output variables, were tested by sensitivity analysis. It indicates how sensitive is the response variable calculated to the observed domain of input variables. Sensitivity values are actual first-order derivatives evaluated at specific centile points for each input variable. For each input, the derivative is taken with respect to the target at ten evenly spaced locations with the observed minimum and maximum values. The exact values are calculated by the Taylor formula (Turanyi\& Tomlin, 2014). The influence of the input over the output variables, i.e. calculated changes of output variables for infinitesimal changes in input variables, as well as the importance of an input variable at a given point in the input space are shown in Figure 1.

Figure 1. Sensitivity analysis of business model in agricultural production in Serbia
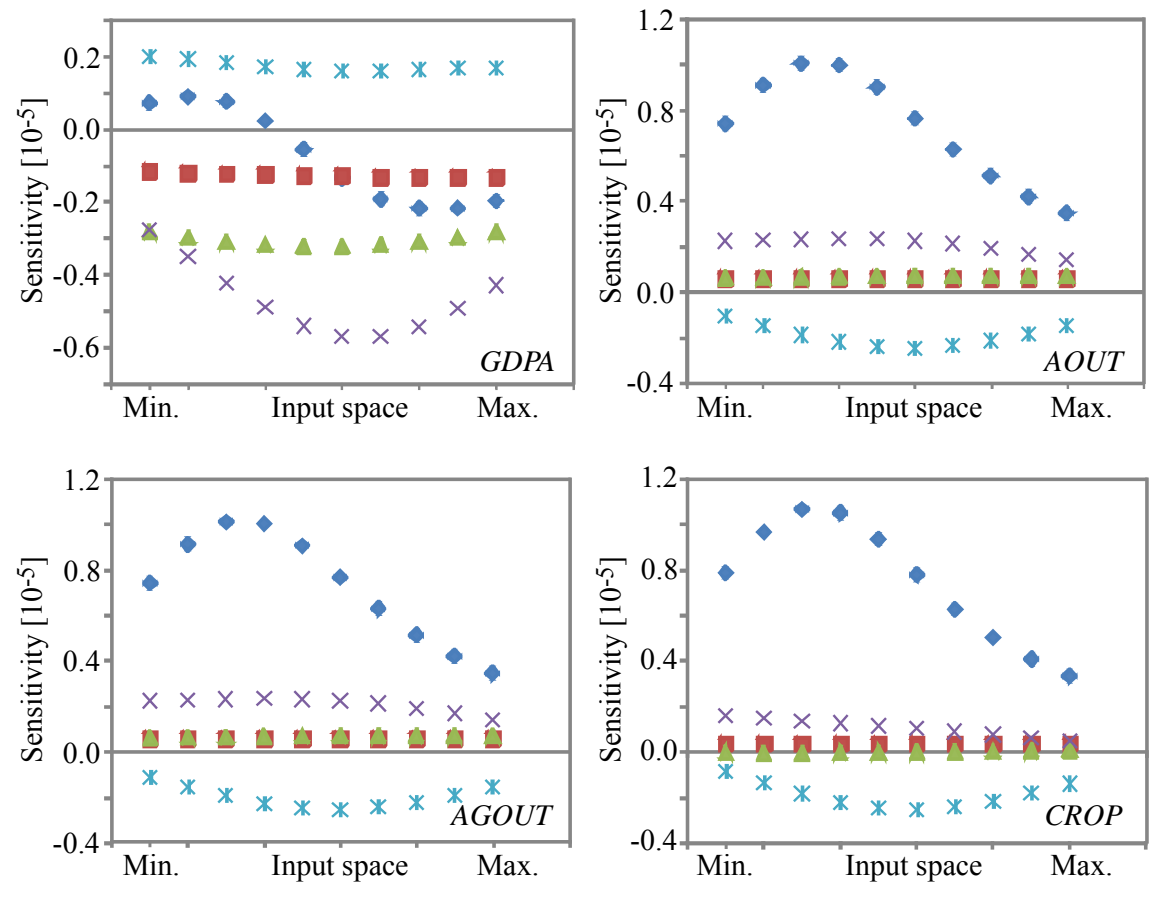

-APRO $\because \mathrm{AVAL} \triangle \mathrm{EMP} \times \mathrm{FER} * \mathrm{FPI}$

GDPA - GDP share agriculture, AOUT - overall agricultural output, AGOUT - agricultural goods output, $C R O P$ - crop production, $A P R O$ - agricultural productivity, $A V A L$ - agricultural value added, CPI - crop production index, EMP - employment in agriculture, FER - fertilizer use and FPI - food production index.

Sensitivity analysis showed that FER is the most important variable for GDPA calculation, while APRO is the most important for the prediction of: AOUT, AGOUT and CROP output variables. The influence of changes in FER on GDPA is most obvious in the centre of the input space for FER (near 140), while the influence of changes in 
APRO on AOUT, AGOUT and CROP is most intensive closer to the minimum of the input space for APRO (close to 5000).

\section{Conclusions}

Despite the fact that Cobb-Douglas production function is widely used method for examining production trends and input contribution to the output, Artificial Neural Network seems to be more accurate indicator of trends in agricultural production in this particular research. This newly developed business model can also be effectively used for prediction of future trends in agricultural production in Serbia.

Using this model, a positive trend has been recorded in the overall agricultural production. Nevertheless, a negative trend is present in the most important output - GDP. The negative trend in GDP of agriculture's share in total nation's GDP can have different causes. One of the reasons may be the inability of the agricultural sector to follow the development path of other, more lucrative economy areas. Obsolete technology applied in agriculture, and lack of investments in the area can be the cause of this fall as well.

Determining the cause of this decrease, and establishing systems to support agricultural GDP is of utmost importance in order to prevent further deterioration in this area of output. If nothing is changed, this negative trend can furthermore lead to decrease in other segments of output in agricultural production observed in this research.

On the other hand, growing trend in fruit production is partially a result of national agricultural strategy and Serbian agro-ecological predetermination for growing of fruits, which is in accordance with world market needs in this area. Therefore, Serbia possesses a great potential for development of value added products in the food industry through valorisation of wastes from this agricultural production. Also, this study presents a good base for the next phase of research where, based on the production trends an overview of generated by-products (wastes) can be perceived, enabling the further step in the transformation towards a circular bioeconomy, by developing the national strategies for sustainable agricultural production.

\section{Acknowledgements}

This article is written within the project III 46005, funded by the Serbian Ministry of Education, Science and Technological Development.

\section{Conflict of interests}

The authors declare no conflict of interest.

\section{References}

1. Apostolov M. (2016). Cobb-Douglas production function on FDI in Southeast Europe, Journal of Economic Structures, 5(10), 1-28. https://papers.ssrn.com/sol3/ papers.cfm?abstract_id=2706657. 
2. Arsenović, M., Pezo, L., Stanković, S., Radojević, Z. (2015). Factor space differentiation of brick clays according to mineral content: Prediction of final brick product quality. Applied Clay Science, 115, 108-114. doi.org/10.1016/j. clay.2015.07.030.

3. Basheer, I. A., Hajmeer, M. (2000). Artificial neural networks: fundamentals, computing, design, and application. Journal of Microbiological Methods, 43, 3-31. doi.org/10.1016/S0167-7012(00)00201-3.

4. Baye, M.R. (2009). Managerial Economics and Business Strategy. McGraw Hill, 82-92. ISBN-13: 978-0073375960, ISBN-10: 0073375969.

5. Belović, M. M., Gironés-Vilaplana, A., Moreno, D. A., Milovanović, I. LJ., Novaković, A. R., Karaman, M. A., Ilić, N. M. (2016). Tomato (Solanum Lycopersicum L.) Processing Main Product (Juice) and By-Product (Pomace) Bioactivity Potential Measured as Antioxidant Activity and Angiotensin-Converting Enzyme Inhibition. Journal of Food Processing and Preservation, 40, 1229-1237. doi.org/10.1111/jfpp.12707.

6. Biam, C. K., Okorie, A., \& Nwibo, S. U. (2016). Economic efficiency of small scale soyabean farmers in Central Agricultural Zone, Nigeria: A Cobb-Douglas stochastic frontier cost function approach. Journal of Development and Agricultural Economics, 8(3), 52-58.

7. Cetojevic-Simin, D., Velicanski, A., Cvetkovic, D., Markov, S., Cetkovic, G., Tumbas Šaponjac, V., Vulic, J., Canadanovic-Brunet, J., Djilas, S. (2015). Bioactivity of Meeker and Willamette raspberry (Rubusidaeus L.) pomace extracts. Food Chemistry, 166, 407-413. 10.1016/j.foodchem.2014.06.063.

8. Chattopadhyay, P. B., Rangarajan, R. (2014). Application of ANN in sketching spatial nonlinearity of unconfined aquifer in agricultural basin. Agricultural Water Management, 133, 81-91. doi.org/10.1016/j.agwat.2013.11.007.

9. Cobb, C. W. Douglas, P. H. (1928). A Theory of Production. American Economic Review, 18,139-165. http://www2.econ.iastate.edu/classes/econ521/Orazem/ Papers/cobb-douglas.pdf.

10. Cook, D. C., Carrasco, L. R., Paini, D. R., Fraser, R. W. (2011). Estimating the social welfare effects of New Zealand apple imports. The Australian Journal of Agricultural and Resource Economics. 55, 599-620. doi.org/10.1111/j.14678489.2011.00558.x.

11. Debertin, D. L. Agricultural Production Economics, (Second Edition, Amazon Createspace, 2012, ISBN-13 978-1469960647.

12. Echevarria, C. (1998). A Three-Factor Agricultural Production Function: The Case of Canada. International Economic Journal, 12 (3), 63-75. doi. org/10.1080/10168739800000029.

13. European Association for Bioindustries (EuropaBio). (2011). Building a Bio-based Economy for Europe in 2020. European Association for Bioindustries: Brussels, 
Belgium.

http://www.scirp.org/(S(oyulxb452alnt1aej1nfow45))/reference/ ReferencesPapers.aspx?ReferenceID=1919890

14. European Bioeconomy Panel. (2014). 2nd Plenary Meeting, Summary of Discussions, 12-13 February. https:/ec.europa.eu/research/bioeconomy/pdf/ bioeconomy-panel-summary-2nd-meeting_en.pdf

15. European Commission. (2012). Communication from the Commission to the European Parliament, the Council, the European Economic and Social Committee and the Committee of the Regions. Innovating for Sustainable Growth: a Bioeconomy for Europe. COM: Brussels, Belgium. http://ec.europa.eu/research/ bioeconomy/pdf/bioeconomycommunicationstrategy_b5_brochure_web.pdf

16. European Commission. (2017). Expert Group Report. Review of the EU Bioeconomy Strategy and its Action Plan. COM: Brussels, Belgium.

17. Ghoshal, P., \& Goswami, B. (2017). Cobb-Douglas Production Function For Measuring Efficiency in Indian Agriculture: A Region-wise Analysis. Economic Affairs, 62(4), 573-579.

18. Grieu, S., Faugeroux, O., Traoré, A., Claudet, B., Bodnar, J. L. (2011). Artificial intelligence tools and inverse methods for estimating the thermal diffusivity of building materials. Energy and Buildings, 43, 543-554. doi.org/10.1016/j. enbuild.2010.10.020.

19. Heijman, W. (2016). How big is the bio-business? Notes on measuring the size of the Dutch bio-economy, NJAS - Wageningen Journal of Life Sciences, 77, 5-8. doi. org/10.1016/j.njas.2016.03.004.

20. Hennig, C., Brosowski, A., Majer, S. (2016). Sustainable feedstock potential - a limitation for the bio-based economy?, Journal of Cleaner Production, 123, 200202. doi.org/10.1016/j.jclepro.2015.06.130.

21. Houthakker, H.S. (1955). The Pareto Distribution and the Cobb-Douglas Production Function in Activity Analysis. The Review of Economic Studies, 23 (1), 27-31. doi. org/10.2307/2296148.

22. Hu, X., Weng, Q. (2009). Estimating impervious surfaces from medium spatial resolution imagery using the self-organizing map and multi-layer perceptron neural networks. Remote Sensing of Environment, 113, 2089-2102. doi.org/10.1016/j. rse.2009.05.014.

23. Johnson, T.G. Altman, I. (2014). Rural development opportunities in the bioeconomy. Biomass Bioenergy, 63, 341-344. doi.org/10.1016/j.biombioe.2014.01.028.

24. Kalt G., Baumann M., Lauk C., Kastner T., Kranzl L., Schipfer F., Lexer M., Rammer W., Schaumberger A., Schriefl E. (2016). Transformation scenarios towards a low-carbon bioeconomy in Austria, Energy Strategy Reviews, 13-14, 125-133. https://www.energyagency.at/fileadmin/dam/pdf/projekte/klimapolitik/ Del.5.2_Transformation_scenarios_towards_a_low-carbon_bi.pdf 
25. Karlović, S., Bosiljkov, T., Brnčić, M., Ježek, D., Tripalo, B., Dujmić, F., Džineva, I., Skupnjak, A. (2013). Comparison of artificial neural network and mathematical models for drying of apple slices pretreated with high intensity ultrasound. Bulgarian Journal of Agricultural Sciences, 19, 1372-1377. http:/www. agrojournal.org/19/06-30.pdf.

26. Kollo, T., von Rosen, D. (2005). Advanced multivariate statistics with matrices. Dordrecht: Springer. ISBN 978-1-4020-3419-0.

27. Loiseau, E., Saikku, L., Antikainen, R., Droste, N., Hansjürgens, B., Pitkänen, K., Leskinen, P., Kuikman, P. Thomsen, M. (2016). Green economy and related concepts: An overview. Journal of Cleaner Production, 139, 361-371. doi. org/10.1016/j.jclepro.2016.08.024.

28. Madamba, P. S. (2002). The Response Surface Methodology: An Application to Optimize Dehydration Operations of Selected Agricultural Crops. LWT - Food Science and Technology, 35, 584-592. doi.org/10.1006/fstl.2002.0914.

29. Maran, J. P., \& Priya, B. (2015). Comparison of response surface methodology and artificial neural network approach towards efficient ultrasound-assisted biodiesel production from muskmelon oil. Ultrasonics Sonochemistry, 23, 192-200. doi:10.1016/j.ultsonch.2014.10.019

30. Mishra, A. K., \& Das, L. (2017). Total factor productivity with Cobb-Douglas production function in agriculture: A Study in Cuttack district, Odisha. South Asian Journal of Marketing \& Management Research, 7(8), 20-25.

31. Montaño, J. J., Palmer, A. (2003). Numeric sensitivity analysis applied to feedforward neural networks. Neural Computing \& Applications, 12, 119-125. 12: 119-125. doi.org/10.1007/s00521-003-0377-9.

32. Montgomery, D. C. (1984). Design and analysis of experiments. (2nd ed.). New York: John Wiley and Sons. ISBN: 978-0-471-72756-9.

33. Muizniece, I., Timma L., Blumberga, A., Blumberga, D. (2016). The methodology for assessment of bioeconomy efficiency. Energy Procedia, 95, 482 - 486. doi. org/10.1016/j.egypro.2016.09.072

34. Pandey, S., Piggott, R. R., Macaulay, T. G. (1982). The elasticity of aggregate Australian agricultural supply: estimates and policy implications. Austialian Journal Agricultural economics, 26 (3), 202-219. http://onlinelibrary.wiley.com/ doi/10.1111/j.1467-8489.1982.tb00413.x/pdf.

35. Pezo, L. L., Ćurčić, B. Lj., Filipović, V. S., Nićetin, M. R., Koprivica, G. B., Mišljenović, N. M., Lević, Lj. B. (2013). Artificial neural network model of pork meat cubes osmotic dehydration. Hemijska industrija, 67, 465-475. http://scindeks. ceon.rs/article.aspx $?$ artid $=0367-598 X 1303465 \mathrm{P}$

36. Pfau, S.F., Hagens, J.E., Dankbaar, B., Smits, A.J.M. (2014). Visions of Sustainability in Bioeconomy Research. Sustainability, 6, 1222-1249. doi:10.3390/su6031222. 
37. Ramcilovic-Suominen, S, Pülzl H. (2017). Sustainable development - A 'selling point' of the emerging EU bioeconomy policy framework? Journal of Cleaner Production, doi:10.1016/j.jclepro.2016.12.157

38. Randall, A. (2008). Is Australia on a sustainability path? Interpreting the clues. The Australian Journal of Agricultural and Resource Economics, 52, 77-95.http:// ageconsearch.umn.edu/record/117742/files/j.1467-8489.2008.00407.x.pdf.

39. Republic of Serbia Strategy of Agriculture and Rural Development of the Republic of Official Gazette 85/2014, Serbia 2014 - 2024, (2014).

40. Ribeiro, C. O., Oliveir, S. M. (2011). A hybrid commodity price-forecasting model applied to the sugar-alcohol sector. The Australian Journal of Agricultural and Resource Economics, 55, 180-198. 10.1111/j.1467-8489.2011.00534.x.

41. Soji-Adekunle, A. R., Asere, A. A., Ishola, N. B., Oloko-Oba, I. M., \& Betiku, E. (2018). Modelling of synthesis of waste cooking oil methyl esters by artificial neural network and response surface methodology. International Journal of Ambient Energy, 1-10.doi:10.1080/01430750.2017.1423378

42. Stajčić, S., Ćetković, G., Čanadanović-Brunet, J., Djilas, S., Mandić, A., ČetojevićSimin, D. (2015). Tomato waste: Carotenoids content, antioxidant and cell growth activities, Food Chemistry, 172, 225-232. doi: 10.1016/j.foodchem.2014.09.069.

43. StatSoft, Inc. STATISTICA (data analysis software system), version 10.0. Available from: http://www.statsoft.com/ (2010).

44. Taylor, B. J. (2006). Methods and procedures for the verification and validation of artificial neural networks. New York: Springer Science \& Business Media. ISBN 978-0-387-29485-8.

45. Trelea, I. C., Raoult-Wack, A. L., Trystram, G. (1997). Note: Application of neural network modelling for the control of dewatering and impregnation soaking process (osmotic dehydration). Food Science and Technology International, 3, 459-465. doi.org/10.1177/108201329700300608.

46. Tumbas Saponjac, V., Girones-Vilaplana, A., Djilas, S., Mena, P., Cetkovic, G., Moreno, D.A., Canadanovic-Brunet, J., Vulic, J., Stajcic, S., Krunic, M. (2014). Anthocyanin profiles and biological properties of caneberry (Rubusspp.) press residues. Journal of Science of the Food and Agriculture, 94, 2393-2400. doi. org/10.1002/jsfa.6564.

47. Tumbas Šaponjac, V., Ćetković, G., Čanadanović-Brunet, J., Pajin, B., Djilas, S., Petrović, J., Lončarević, I., Stajčić, S., Vulić, J. (2016). Sour cherry pomace extract encapsulated in whey and soy proteins: Incorporation in cookies. Food Chemistry, 207, 27-33. doi.org/10.1016/j.foodchem.2016.03.082.

48. Turanyi, T., Tomlin, A. S. (2014). Analysis of Kinetics Reaction Mechanisms. Berlin Heidelberg: Springer. ISBN 978-3-662-44562-4. 
49. Ubilava, D., Holt, M. (2013). El Nino southern oscillation and its effects on world vegetable oil prices: assessing asymmetries using smooth transition models, The Australian Journal of Agricultural and Resource Economics, 57, 273-297. doi. org/10.1111/j.1467-8489.2012.00616.x

50. Vanzetti, D., Quiggin, J. (1985). A comparative analysis of agricultural tractor investment models, Australian Journal of Agricultural Economics, 29 (2), 122141. doi.org/10.1111/j.1467-8489.1985.tb00652.x

51. Yuan Z. (2011). Analysis of agricultural input-output based on Cobb-Douglas production function in Hebei Province, North China. African Journal of Microbiology Research, 5 (32), 5916-5922. doi.org/10.5897/AJMR11.961.

52. Zabaniotou, A., Rovas, D., Delivand, M. K., Francavilla, M., Libutti, A., Cammerino, A. R., \& Monteleone, M. (2017). Conceptual vision of bioenergy sector development in Mediterranean regions based on decentralized thermochemical systems. Sustainable Energy Technologies and Assessments, 23, 33-47. doi. org/10.1016/j.seta.2017.09.006

53. Zeng, W., Xu, C., Zhao, G., Wu, J., \& Huang, J. (2017). Estimation of Sunflower Seed Yield Using Partial Least Squares Regression and Artificial Neural Network Models. Pedosphere. doi:10.1016/s1002-0160(17)60336-9

\section{Suplement material}

Table S1. Input values for the Agrotechnical model, collected from the Global Economy site

\begin{tabular}{|c|c|c|c|c|c|c|}
\hline & $\begin{array}{c}\text { APRO } \\
(\text { USD) }\end{array}$ & $\begin{array}{c}\text { AVAL } \\
\text { (billion } \\
\text { USD) }\end{array}$ & $\begin{array}{c}\text { CPI } \\
(-)\end{array}$ & $\begin{array}{c}\text { EMP } \\
(\%)\end{array}$ & $\begin{array}{c}\text { FER } \\
(\mathrm{kg} / \mathrm{h} \text { a arable } \\
\text { land })\end{array}$ & $\begin{array}{c}\text { FPI } \\
(-)\end{array}$ \\
\hline 2007 & 4343.35 & 3.42 & 90.39 & 20.71 & 152.99 & 97.32 \\
\hline 2008 & 4888.54 & 4.28 & 103.30 & 25.02 & 114.09 & 100.62 \\
\hline 2009 & 4858.93 & 3.49 & 108.77 & 23.71 & 143.11 & 106.77 \\
\hline 2010 & 5374.52 & 3.44 & 103.39 & 22.10 & 115.80 & 101.37 \\
\hline 2011 & 5693.10 & 4.27 & 106.07 & 21.09 & 126.20 & 104.23 \\
\hline 2012 & 4893.95 & 3.14 & 75.58 & 20.88 & 171.38 & 91.96 \\
\hline 2013 & 6208.40 & 3.69 & 107.75 & 21.16 & 154.84 & 108.51 \\
\hline
\end{tabular}

$A P R O$ - agricultural productivity, $A V A L$ - agricultural value added, CPI - crop production index, EMP - employment in agriculture, FER - fertilizer use and FPI - food production index. 
Economics of Agriculture, Year 66, No. 2, 2019, (pp. 437-456), Belgrade

Table S2. Output values for the Agrotechnical model, obtained from the Serbian economic statistical yearbooks

\begin{tabular}{|c|c|c|c|c|c|c|c|c|}
\hline Year & GDPA & AOUT & AGOUT & CROP & CER & ICRO & FOR & VEG \\
\hline 2007 & 10.51 & 330174 & 320756 & 217274 & 90749 & 26549 & 12761 & 22585 \\
\hline 2008 & 10.99 & 417832 & 407406 & 278825 & 134575 & 32309 & 14147 & 24879 \\
\hline 2009 & 10.21 & 407851 & 396221 & 265101 & 110384 & 30737 & 14586 & 28753 \\
\hline 2010 & 10.89 & 466811 & 455753 & 328981 & 146733 & 44619 & 17601 & 42902 \\
\hline 2011 & 11.38 & 519960 & 509125 & 359103 & 175221 & 46655 & 17184 & 27246 \\
\hline 2012 & 9.76 & 502684 & 491597 & 324451 & 138325 & 52806 & 18693 & 28986 \\
\hline 2013 & 10.16 & 544442 & 531469 & 358223 & 157155 & 51487 & 16626 & 27375 \\
\hline Year & POT & FRU & WINE & OCRO & ANIP & ANIM & CATT & PIG \\
\hline 2007 & 8318 & 33929 & 21795 & 587 & 103482 & 69001 & 21439 & 32955 \\
\hline 2008 & 8314 & 39324 & 24758 & 521 & 128581 & 87759 & 24736 & 46734 \\
\hline 2009 & 9747 & 37040 & 33316 & 538 & 131119 & 95853 & 26700 & 51192 \\
\hline 2010 & 17695 & 41159 & 17873 & 399 & 126772 & 89606 & 24797 & 45392 \\
\hline 2011 & 17870 & 50860 & 23713 & 355 & 150022 & 102774 & 29059 & 48768 \\
\hline 2012 & 12342 & 53932 & 18925 & 443 & 167146 & 113463 & 31377 & 58642 \\
\hline 2013 & 19102 & 58404 & 27535 & 540 & 173246 & 118893 & 32407 & 60983 \\
\hline Year & EQU & SHEEP & POUL & ANIP2 & MILK & EGG & OANI & ASERV \\
\hline 2007 & 129 & 6524 & 7954 & 34482 & 25352 & 8288 & 842 & 9418 \\
\hline 2008 & 118 & 6771 & 9401 & 40821 & 30397 & 9704 & 721 & 10426 \\
\hline 2009 & 105 & 7363 & 10523 & 35266 & 25480 & 8649 & 1137 & 11630 \\
\hline 2010 & 61 & 8516 & 10839 & 37166 & 26943 & 8608 & 1615 & 11058 \\
\hline 2011 & 61 & 9315 & 15572 & 47248 & 34212 & 10810 & 2226 & 10834 \\
\hline 2012 & 377 & 7801 & 15266 & 53684 & 36777 & 14678 & 2229 & 11087 \\
\hline 2013 & 203 & 8121 & 17179 & 54353 & 38018 & 13395 & 2940 & 12973 \\
\hline
\end{tabular}

GDPA - GDP share agriculture, AOUT - overall agricultural output, AGOUT - agricultural goods output, $C R O P$ - crop production, $C E R$ - the production of cereals (including seeds), $I C R O$ - the production of industrial crops, FOR - the production of forage plants, VEG - the production of vegetables and horticultural products, $P O T$ - the production of potato (including seeds), FRU - the production of fruits, WINE - the production of wine, OCRO - other crop products, ANIP - the overall animal production, ANIM - the production of animals, CATT - the production of cattle, PIG - the production of pigs, EQU - the production of equines, SHEEP - the production of sheep and goats, POUL - the production of poultry, ANIMP2 - the overall collection of animal products, MILK - milk products, EGG - eggs production, OANI - other animal products and ASERV - agricultural services. 
Table S3 ANOVA calculation of collected data (sum of squares)

\begin{tabular}{|l|c|c|c|c|c|c|c|c|}
\hline & GDPA & AOUT & AGOUT & CROP & CER & ICRO & FOR & VEG \\
\hline APRO & 0.001 & 0.140 & 0.144 & 0.146 & 0.185 & 0.350 & 0.078 & 0.053 \\
\hline AVAL & 0.002 & 0.000 & 0.000 & 0.000 & 0.005 & 0.007 & 0.009 & 0.162 \\
\hline EMP & 0.003 & 0.007 & 0.007 & 0.002 & 0.002 & 0.003 & 0.001 & 0.000 \\
\hline FER & 0.006 & 0.003 & 0.003 & 0.000 & 0.002 & 0.001 & 0.001 & 0.117 \\
\hline FPI & 0.000 & 0.027 & 0.029 & 0.027 & 0.050 & 0.112 & 0.031 & 0.002 \\
\hline & POT & FRU & WINE & OCRO & ANIP & ANIM & CATT & PIG \\
\hline APRO & 0.307 & 0.168 & 0.014 & 0.036 & 0.138 & 0.141 & 0.079 & 0.179 \\
\hline AVAL & 0.042 & 0.007 & 0.019 & 0.000 & 0.002 & 0.000 & 0.001 & 0.001 \\
\hline EMP & 0.059 & 0.004 & 0.029 & 0.014 & 0.027 & 0.036 & 0.015 & 0.090 \\
\hline FER & 0.056 & 0.035 & 0.081 & 0.045 & 0.045 & 0.039 & 0.034 & 0.055 \\
\hline FPI & 0.001 & 0.048 & 0.100 & 0.029 & 0.033 & 0.022 & 0.013 & 0.029 \\
\hline & $E Q U$ & SHEEP & POUL & ANIP2 & MILK & EGG & OANI & ASERV \\
\hline APRO & 0.302 & 0.027 & 0.286 & 0.136 & 0.105 & 0.176 & 0.763 & 0.027 \\
\hline AVAL & 0.014 & 0.001 & 0.007 & 0.021 & 0.026 & 0.017 & 0.023 & 0.004 \\
\hline EMP & 0.503 & 0.006 & 0.005 & 0.011 & 0.008 & 0.030 & 0.022 & 0.010 \\
\hline FER & 1.381 & 0.008 & 0.063 & 0.060 & 0.046 & 0.114 & 0.036 & 0.005 \\
\hline FPI & 0.504 & 0.001 & 0.044 & 0.069 & 0.057 & 0.109 & 0.043 & 0.001 \\
\hline
\end{tabular}

GDPA - GDP share agriculture, AOUT - overall agricultural output, AGOUT - agricultural goods output, $C R O P$ - crop production, $C E R$ - the production of cereals (including seeds), $I C R O$ - the production of industrial crops, FOR - the production of forage plants, VEG - the production of vegetables and horticultural products, $P O T$ - the production of potato (including seeds), FRU - the production of fruits, WINE - the production of wine, OCRO - other crop products, ANIP - the overall animal production, ANIM - the production of animals, CATT - the production of cattle, PIG - the production of pigs, EQU - the production of equines, SHEEP - the production of sheep and goats, POUL - the production of poultry, ANIMP2 - the overall collection of animal products, MILK - milk products, EGG - eggs production, OANI - other animal products and ASERV - agricultural services.

$A P R O$ - agricultural productivity, $A V A L$ - agricultural value added, CPI - crop production index, EMP - employment in agriculture, FER - fertilizer use and FPI - food production index. 